稀な部位に発生した骨端線離開

鹿児島大学整形外科

東 成 昭・田 中 源 郎
柚 紘一郎 -内 村 暢二郎

鶴 留 整形外科

鶴 留 寿人

\title{
3 Cases of Epiphysial Separation
}

By

\author{
N. Higashi, M. Tanaka, K. Yunoki and Y. Uchimura \\ Department of Orthopaedic Surgery, Kagoshima University, \\ Faculty of Medicine \\ H. Tsurudome \\ Tsurudome Hospital
}

Three rare traumatic epiphysial separation were presented. Two of them were the first metacarpal bone, the other was distal tibia. These cases were treated conservatively except one.

最近ソフトボールによる第 1 中手骨近位骨端線離開 の 2 例, 自転車転倒による脛骨遠位骨端線離開の 1 例 を経験し，何れも稀な部位に発生したあのなので報告 する.

\section{症例}

症例 $1: 13$ 才, 男子

昭和 52 年 11 月 13 日ソフトボールの試合中, 左手 にグローブをはめたまま転倒した際, 左手を石にぶっ つけ, 左 $\mathrm{CM}$ 関節部の 腫脹を来たし 来院した. $\mathrm{X}$ 線 にて左第 1 中手骨近位骨端線離開と近位骨幹端の外側 転位がみられる．血液検查で異常所見はみられない。

まず左前腕より M P 関節にかけ, 前腕届側に Cramer シーネをあて, 前腕部をギプスにて固定した. ついで左母指に絆創育を巻き，てれと Cramer シー ネとを輪ゴムにて結び，母指の充分な伸展を計り， $\mathrm{X}$ 線透視を行ないながら C M関節外側にローラー状に丸 めたガーゼをあて，徒手にて圧迫整復し，弾力包帯に て固定した. 1 力月後てれらの装具は除去したが現在 機能障害はみられない（図 1，2）.

症例 2:12才, 男子
昭和 52 年 11 月 23 日ソフトボール試合中捕手をし ていて，左手にグローブをはめたままランナーにタッ チした後, 左 $\mathrm{CM}$ 関節部の疼痛, 腫脹を来たして来院 した．X線にて左第 1 中手骨近位骨端線離開と近位骨 幹端の内側転位がみられる．血液検查で異常はみられ ない.

保存的治療を試みるも整復不能のため観血的に整復 し, Kirschner 鋼線にて固定した. 1 力月後抜釷し, 後療法を行なったが何ら機能障害はみられない（図 $3)$.

症例 $3: 13$ 才, 男子

昭和 51 年 7 月 11 日自転車で 転倒, 右足関節 の 動 摇, 腫脹, 疼痛を来たし来院した. $\mathrm{X}$ 線撮影により右 脛骨遠位端に骨折をともなう骨端線離開, 腓骨の屈曲 骨折が認められる.

透視下にて徒手整復しギプス固定した. 1 力月後 骨嘴合良好のためギプス除去, 後療法を行なったが現 在機能障害はみられない（図 4).

考

按

骨端線離開は骨端線の閉鎖する以前の若年者に発生 


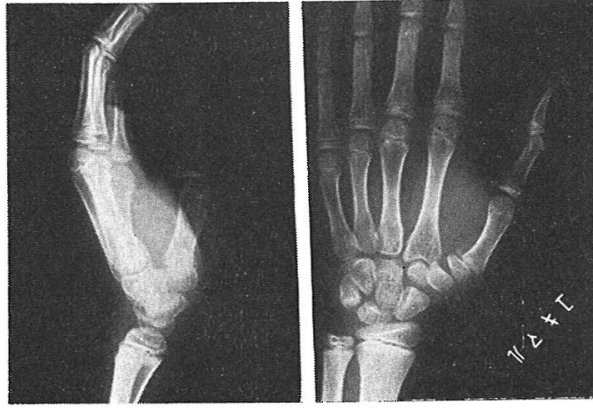

受 傷 洔

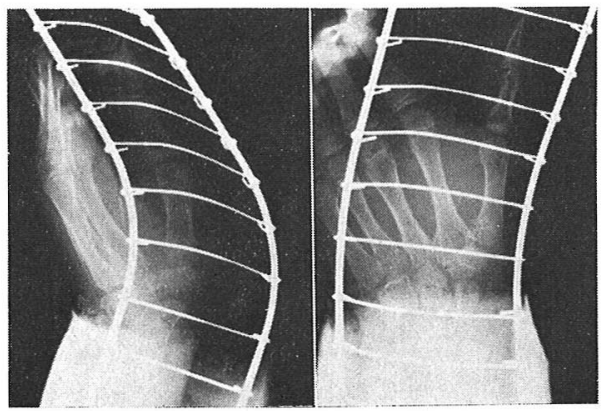

整 復 後

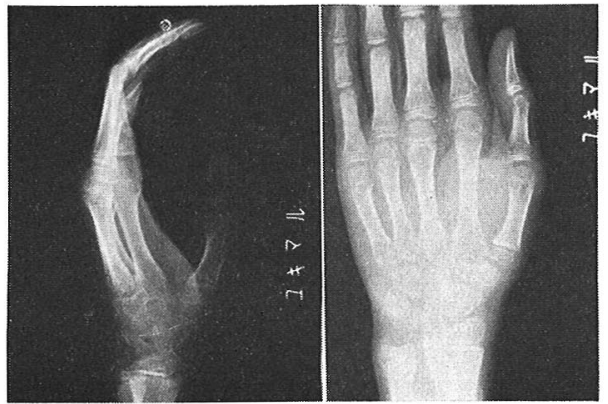

1 力月後

図 1 症例 1

する. その原因として外傷が重要な役割を占めるが， そのほかに炎症, 内分泌障害によっても起こることが ある．以前著者ら1は本誌に骨端線離開について述べ たことがあるが，その中であ大腿骨頭认り症は特異な もので, 治療には種々の考虑が必要である. 今回経験 し，報告した症例は全例外傷性である。

脛骨遠位に関しては Neer II ${ }^{4)}$ の 2500 例の Epiphysial Fractures の集計において low tibia は11 \%を占め，また Crenshaw ${ }^{3)}$ は Injuries of the Distal Tibial Epiphysis と題して Campbell cli-

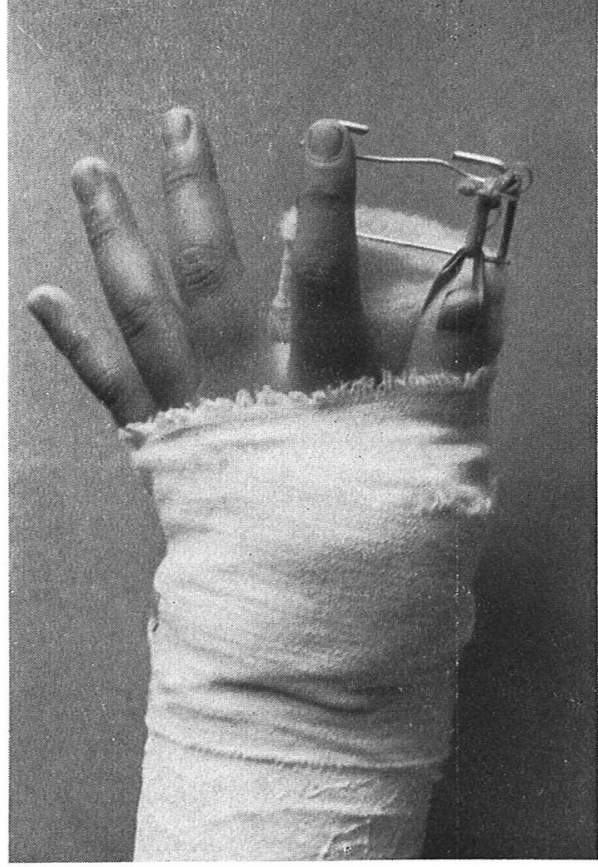

図 2 症例 1

nic における54 例を調査, 報告しており，国外では そう稀なものではないと思われるが，本邦における報 告は少ない。

一方第 1 中手骨近位骨端線離開については全く記載 がなく, Bount ${ }^{2)}$ の著書の中にあ所謂 Bennet 骨折 は若年層に拈いてはみられるととはないと記してある だけである. また Epiphysial Injury の分類として 一般に採用されている Salter \& Harris ${ }^{5)}$ の文献 によっても phalangeal epiphysial plate の損傷 は最も少なく, proximal または middle phalanx basis 部の損傷は非常に稀であるとの記載はあるが, 中手骨の骨端線損傷については全く記載がない。同様 にわれわれの渉粆した範囲では本邦における報告, 記 載む見当らず，本邦初例ではないかと考えられる. と ころでわれわれの 2 症例は何れもソフトボールに関係 しているが，最近各町村にナイター設備をもつソフト ボールが盛んになり，特に手の外傷が増加してきてい る. 子供においても受傷の機会が増えたことやふつう の軟式球に比べて重量のあるボールの衝撃が骨端線䦥 鎖以前の子供の手に加わるととなどが原因かと思われ る.

骨端線離開の治療は保存的治療が原則であるが, 症 


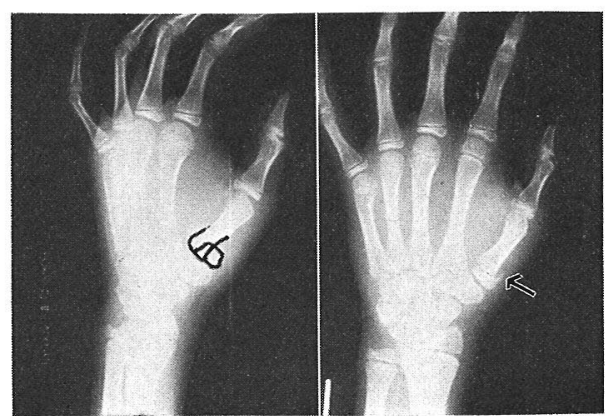

受 傷 時

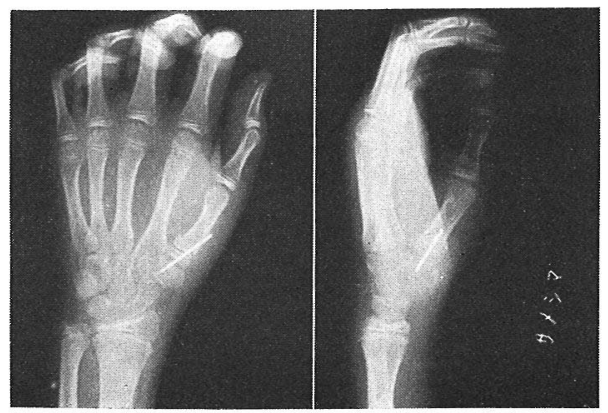

整 復 後

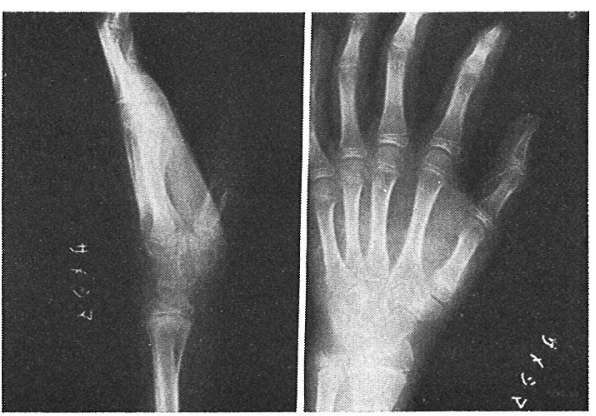

1 力月後

図 3 症例 2

例 2 のような場合は観血的整復術が必要となる.

結語

中手骨近位，脛骨遠位の稀な部位の骨端線離開を経 験したので報告した。

$$
\text { 文献 }
$$

1）東 成昭 - 他：整形外科と災害外科，25：260, 1976.

2) Blount, R. E. : Fracture in Clildren, Williams \& Wilkins, Baltimore, 1955.

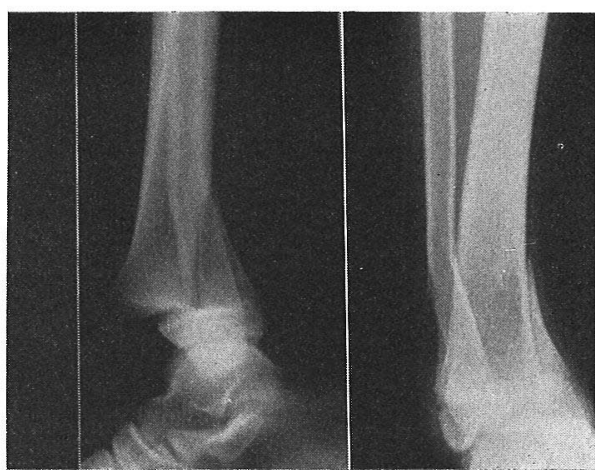

受 傷 時

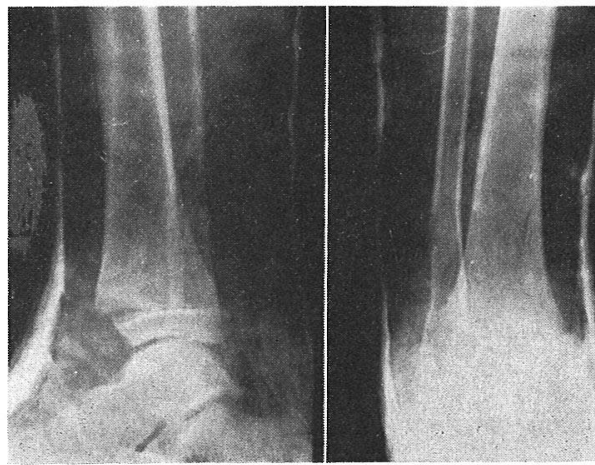

整 復 後

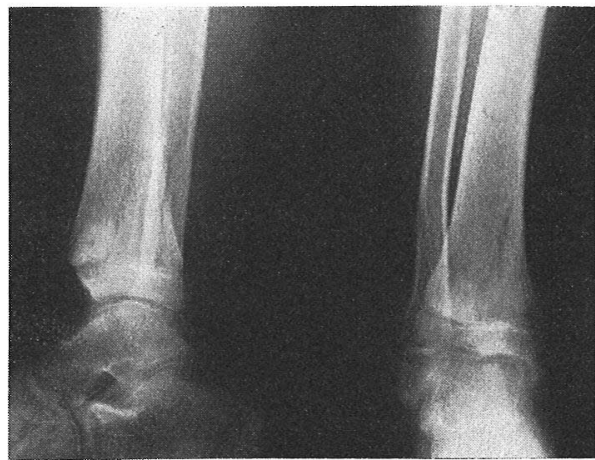

1 力月後

図 4 症例 3

3) Crenshaw, A. H.: Clin. Orthop. 41: 98, 1965.

4) Neer II, C. S. and Horwitz, B. S.: Clin. Orthop. 41: 24, 1965.

5) Salter, R. B. and Harris, W. R.: J. Bone Joint Surg. 45-A : 588, 1963. 


\section{質問·追加 九州労災病院 鳥巣 岳彦}

1) 骨端線離開という言質より骨端線損傷とした方 がよいのではないか.

2 ) 症例 3 の骨折型は小児の脛骨遠位端で頻繁認め られる骨折型 (Salter-Harris 分類第 2 型) です.

回答鹿大 東成昭 fracture という言葉がある位で離開に骨折を伴うこ とが多いからと思われる．骨折を伴わなければやはり 離開とすべきと思う. 国外では骨折を伴わない plate の rotation という言葉もある. 脛骨下端の症例は講 演中述べたでとく国外で多いので本邦でも多いのでは ないかと考えている．しかし実際報告は日本では少な い. 一方，中手骨に関しては手の外科関係にも問い合 せたが 1 例もない。 